\title{
KAJIAN STRATEGI IMPLEMENTASI KESATUAN \\ PENGELOLAAN HUTAN (KPH): STUDI KASUS DI KABUPATEN TANA TORAJA, PROVINSI SULAWESI SELATAN
}

\section{(Study of the Implementation Strategy of Forest Management Unit: Case Study in Tana Toraja Regency, South Sulawesi Province)}

\author{
Oleh/By: \\ Achmad Rizal HB ${ }^{1}$, Indah Novita Dewi ${ }^{2} \&$ Priyo Kusumedi ${ }^{3}$ \\ ${ }^{1,2}$ Balai Penelitian Kehutanan Makassar, Jln. Perintis Kemerdekaan KM 16,5 Makassar \\ Telp. (0411) 554049, Fax (0411) 554058 \\ E-mail: arhbisjoe@yahoo.com, indahnovitadewi@yahoo.com \\ ${ }^{3}$ Balai Penelitian Kehutanan Solo, Jln. Jend. Ahmad Yani, Kartasura \\ Telp. (0271) 716709, Fax (0271) 716959 \\ E-mail: p_kusumedi@yahoo.com
}

\begin{abstract}
In the concept of KPH (Kesatuan Pengelolaan Hutan or Forest Management Unit $=F M U)$, forest area is divided into several management units which can be efficiently and sustainably managed (PP 6/2007 jo PP3/2008). It was initiated by establishing KPH Model or Model of FMU, for example in Tana Toraja Regency in 2005. So far, the concept of KPH can not be implemented yet. The aim of this research is to formulate the implementation strategy of KPH development in South Sulawesi through case study in Tana Toraja Regency. The data was collected by applying several methods, consist of: desk study, survey, interviewe, and FGD (Focus Group Discussion) and then analysed by applying qualitative and quantitative descriptive methods. Force Field Analysis (FFA) was applied in formulating the implementation strategy. The result showed that there are some driving factors and some restraining factors in KPH development internally and externally. The concept of KPH and its related regulation should be socialized more intensively by involving the primary stakeholders. The development of KPH in Tana Toraja Regency is in "growthstability" category. The recommended alternative strategy is concentration through horizontal integrated. This strategy is part of the growth strategy and can be done by expanding the activities with the community and developing information and communication networking with other regency that have KPH program.
\end{abstract}

Keyrword:FMU or KPH, implementation strategy, growth-stability

\section{ABSTRAK}

Konsep KPH (Kesatuan Pengelolaan Hutan) membagi kawasan hutan menjadi wilayah pengelolaan hutan terkecil sesuai fungsi pokok dan peruntukannya yang dapat dikelola secara efisien dan lestari (PP 6/2007 jo PP 3/2008) yang dimulai dengan pembangunan KPH Model. 
Satu di antaranya adalah KPH Model di Kabupaten Tana Toraja yang telah dicanangkan pada tahun 2005. Sejauh ini, konsep KPH belum dapat diimplementasikan di kabupaten tersebut. Penelitian ini bertujuan untuk merumuskan strategi implementasi pembangunan KPH di Sulawesi Selatan dengan studi kasus di Kabupaten Tana Toraja. Metode pengumpulan data meliputi: desk study, survei, wawancara, dan FGD (Focus Group Discussion). Data yang dihimpun, selanjutnya dianalisis dengan analisis deskriptif kualitatif dan kuantitatif. Untuk merumuskan strategi implementasi KPH, digunakan analisis medan daya (Force Field Analysis = FFA). Hasil kajian menunjukkan adanya beberapa faktor pendorong dan faktor penghambat, baik internal maupun eksternal dalam implementasi KPH. Konsep KPH dan peraturan terkait perlu disosialisasikan secara intensif dengan melibatkan stakeholder kunci. Pembangunan KPH Tana Toraja berada pada kategori growth-stability, dengan strategi alternatif yang disarankan adalah konsentrasi melalui integrasi horizontal. Strategi ini termasuk dalam strategi pertumbuhan dengan cara memperluas kegiatan di masyarakat dan mengembangkan jaringan informasi dan komunikasi antar daerah yang memiliki program $\mathrm{KPH}$.

Kata kunci: KPH, strategi implementasi, growth-stability

\section{PENDAHULUAN}

Konsep Kesatuan Pengelolaan Hutan (KPH) merupakan satu di antara upaya mengatasi permasalahan kehutanan Indonesia yang kondisinya makin memprihatinkan, yang ditandai dengan meningkatnya laju degradasi hutan, kurang berkembangnya investasi di bidang kehutanan, rendahnya kemajuan pembangunan hutan tanaman, kurang terkendalinya illegal logging dan illegal trade, merosotnya perekonomian masyarakat di dalam dan sekitar hutan, serta meningkatnya luas kawasan hutan yang tidak terkelola secara baik. Melalui KPH diharapkan dapat dilakukan upaya-upaya strategis dalam bentuk deregulasi dan debirokratisasi kehutanan dengan pendekatan multi-pihak.

$\mathrm{KPH}$ adalah wilayah pengelolaan hutan sesuai fungsi pokok dan peruntukannya, yang dapat dikelola secara efisien dan lestari. Konsep KPH sebenarnya mulai diwacanakan sejak diberlakukannya UU No.5/1967 yang pada masa itu diartikan sebagai Kesatuan Pemangkuan Hutan, sebagaimana diterapkan dalam pengelolaan hutan oleh Perum Perhutani di Pulau Jawa. Dalam UU 41/1999 konsep ini kembali dimunculkan yang kemudian diikuti dengan aturan pedoman pembentukannya seperti tertuang dalam beberapa peraturan perundang-undangan. Konsep KPH memiliki payung hukum dengan dikeluarkannya PP 6/2007 jo PP 3/ 2008 tentang Tata Hutan dan Penyusunan Rencana Pengelolaan Hutan serta Pemanfaatan Hutan, di mana berdasarkan konsep tersebut kawasan hutan di Indonesia terbagi dalam $\mathrm{KPH}$, yang menjadi bagian dari penguatan sistem pengurusan hutan nasional, pemerintah provinsi dan pemerintah kabupaten/kota. 
Untuk mewujudkan pengelolaan hutan secara lestari maka seluruh kawasan hutan terbagi ke dalam KPH. KPH tersebut dapat berbentuk Kesatuan Pengelolaan Hutan Konservasi (KPHK), Kesatuan Pengelolaan Hutan Lindung (KPHL) maupun Kesatuan Pengelolaan Hutan Produksi (KPHP) tergantung dari fungsi yang luasnya dominan. Fungsi yang luasnya dominan adalah apabila dalam satu wilayah KPH terdiri lebih dari satu fungsi hutan, misalnya terdiri dari hutan yang berfungsi produksi dan hutan yang berfungsi lindung, dan jika areal dari salah satu fungsi hutan, misalnya fungsi produksi, lebih luas atau mendominasi areal yang berfungsi lindung, maka KPH tersebut dinamakan KPH Produksi (KPHP). Penentuan nama KPH berdasarkan fungsi yang luasnya dominan adalah untuk efektifitas dan efisiensi pengelolaannya.

$\mathrm{KPH}$ dapat ditetapkan dalam: (i) satu atau lebih fungsi hutan, (ii) lintas wilayah administrasi pemerintahan dan atau dalam satu wilayah administrasi. Luasan satu KPH ditetapkan dengan memperhatikan efisiensi dan efektifitas pengelolaan hutan dalam satu wilayah DAS atau satu kesatuan wilayah ekosistem. Keberadaan suatu KPH tidak dipengaruhi oleh perubahan RTRWP maupun RTRWK. KPH perlu dibentuk berdasarkan keterkaitan komponen ekosistem dan tidak dipisah-pisahkan menurut fungsi pokok dan peruntukannya.

Kondisi hutan di Provinsi Sulawesi Selatan sampai saat ini adalah luas daratan yang masih berupa hutan (berhutan) adalah sebesar 34,44\% dan daratan yang bukan berupa hutan (non hutan) sebesar 56,85\%. Penutupan lahan non hutan adalah penutupan lahan selain daratan yang bervegetasi hutan yaitu berupa semak/belukar, lahan tidak produktif, sawah, lahan pertanian, pemukiman, alang-alang dan lainlain. Kondisi kawasan hutan tersebut mengalami laju pengurangan hutan (deforestasi) selama periode waktu 13 tahun dengan rata-rata laju deforestasi sekitar 58.807 ha/tahun (Badan Planologi Kehutanan, 2005).

Berdasarkan analisis peta penafsiran citra landsat di kawasan hutan produksi, hutan lindung dan konservasi serta dengan mempertimbangkan DAS prioritas, diperoleh suatu indikasi lahan yang perlu di rehabilitasi sebagai lahan kritis dengan luas keseluruhan sekitar 1.174 .706 ha $(33,2 \%)$ yang terdiri dari hutan lindung dan konservasi 755.136 ha serta kawasan hutan produksi 419.571 ha (Balai Pemantapan Kawasan Hutan Wilayah VII Makassar, 2005). Kondisi ini tidak terlepas dari kegiatan perambahan, kebakaran hutan, illegal logging dan kegiatan legal lainnya seperti konversi lahan untuk perumahan dan pembukaan jalan maupun pemekaran wilayah. Hampir seluruh kawasan hutan yang ada tidak terlepas dari konflik akses pemanfaatan hutan dan lahan dengan masyarakat dan kepentingan lainnya sehingga sangat berpengaruh dalam pengelolaan hutan di masa datang.

Dari kondisi di atas, maka di Sulawesi Selatan telah dibangun KPH Model yang diinisiasi oleh Badan Planologi yaitu KPH Model Tana Toraja sebagai show window dalam tahap awal pembangunan KPH. Pembangunan KPH tersebut 
diharapkan dapat memecahkan permasalahan mendasar dalam pengelolaan dan pengurusan hutan. Permasalahan tidak hanya pada pembangunan unit pengelolaan, tetapi juga pada sistem perencanaan (rencana pengelolaan jangka panjang dan pendek) serta berfokus pada pembangunan institusi pengelola (kelembagaan) yang perlu diikuti dengan pengembangan infrastruktur di tingkat kabupaten/kota/provinsi.

Ketiadaan struktur yang memadai (institusi pengelola $\mathrm{KPH}$ ) menyebabkan penyelenggaraan administrasi pemerintahan menjadi tidak efektif dalam menjaga kelestarian hutan. Permasalahan selanjutnya adalah implementasi konsep rancang bangun tersebut di tingkat lapang, yang kemungkinan besar menghadapi kendalakendala, baik dari faktor sosial maupun ekonomi masyarakat di dalam dan sekitar kawasan hutan.

Agar permasalahan tersebut tidak menjadi kendala dalam pembangunan $\mathrm{KPH}$, diperlukan suatu kajian yang menyeluruh tentang rancang bangun dan implementasinya baik dari aspek unit pengelolaan, rencana pengelolaan maupun institusi pengelolaan. Sementara untuk lebih detailnya perlu dianalisis baik dari segi kebijakan, kelembagaan, dan para pihak yang terlibat (stakeholder). Untuk tahap pendahuluan, dilakukan kajian mengenai unit pengelolaan hutan yang meliputi kegiatan antara lain 1) tata hutan dan penyusunan rencana pengelolaan hutan; 2) pemanfaatan hutan; 3) penggunaan kawasan hutan; 4) rehabilitasi hutan dan reklamasi; dan 5) perlindungan hutan dan konservasi alam.

Penelitian ini bertujuan untuk merumuskan strategi implementasi pembangunan KPH di Sulawesi Selatan dengan studi kasus di Kabupaten Tana Toraja dengan fokus pada pilar pemerintah selaku pihak pengambil kebijakan.

\section{METODE PENELITIAN}

\section{A. Lokasi dan Waktu Penelitian}

Penelitian dilaksanakan di Kabupaten Tana Toraja, Sulawesi Selatan dan berlangsung pada Februari 2009-Desember 2009.

\section{B. Bahan dan Alat}

Bahan dan peralatan yang digunakan dalam penelitian ini adalah: alat tulis menulis, alat perekam, peta lokasi, kuesioner, kamera, dan perlengkapan lapang.

\section{Tahapan Pelaksanaan}

Tahapan pelaksanaan penelitian mengacu kepada prinsip-prinsip PRA (Participatory Rural Appraisal) dengan rangkaian kegiatan, sebagai berikut : 1) 
Konsultasi dan diskusi tentang hasil penelitian sebelumnya; 2) Koordinasi dan sosialisasi dengan parapihak; 3) Observasi areal pencadangan KPH; 4) Wawancara mendalam terhadap representasi petani hutan secara purposif; dan 5) Pertemuan pleno dan diskusi kelompok.

Metode pengumpulan data yang digunakan meliputi : desk study, survei, wawancara (konsultasi), dan FGD (focus group discussion), dengan penjelasan sebagai berikut:

1. Desk study dengan bahan referensi hasil-hasil penelitian yang telah ada tentang pembangunan KPH yang berasal dari berbagai lembaga penelitian serta produkproduk peraturan perundangan yang berkaitan dengan $\mathrm{KPH}$.

2. Survei dalam rangka pengumpulan data kuantitatif dan data kualitatif berupa pendapat pejabat kunci pada instansi terkait dan masyarakat serta kalangan LSM, dalam rangka validasi (pengayaan hasil desk study).

3. Wawancara (konsultasi) dan FGD dengan parapihak (stakeholder) yang berkaitan langsung dengan pembangunan KPH serta pakar yang terkait dari lembaga penelitian dan universitas.

Jenis data yang dikumpulkan dalam penelitian ini adalah data primer dan sekunder. Data primer dikumpulkan langsung di lapang dari sumber data pertama, baik melalui wawancara, maupun teknik survei maupun non-survei dan memerlukan validitas yang harus dibandingkan, baik dengan sumber data primer lainnya maupun data sekunder. Data sekunder dihimpun melalui penelusuran pustaka yang relevan dengan penelitian ini, baik berupa laporan-laporan dari dinas terkait, instansi penelitian, perguruan tinggi, dan data terkait lainnya.

\section{Analisis Data}

Data yang dihimpun dalam penelitian KPH, selanjutnya dianalisis dengan analisis deskriptif kualitatif \& kuantitatif. Adapun untuk merumuskan strategi implementasi KPH digunakan analisis medan daya (Force Field Analysis) dari Kurt Lewin, yang dikembangkan oleh Morgan (2008) dan secara partisipatif telah diterapkan oleh Singer (2009) dalam suatu analisis kekuatan-kekuatan yang mendukung dan yang menghambat terwujudnya perubahan. Selanjutnya, Singer (2009) mengemukakan langkah-langkah analisis, sebagai berikut:

1. Menuliskan semua faktor pendorong terjadinya perubahan pada sisi kiri kertas.

2. Menuliskan semua faktor penghambat terjadinya perubahan pada sisi kanannya.

3. Memberikan nilai setiap faktor pendorong dan penghambat $1-5$, di mana $1=$ paling lemah pengaruhnya sampai dengan $5=$ paling kuat pengaruhnya.

4. Menjumlahkan nilai masing-masing faktor secara terpisah untuk keperluan analisis cepat terhadap faktor pendorong dan faktor penghambat.

5. Membentuk kelompok (terdiri dari 3 - 4 orang) untuk mendiskusikan cara memperkuat faktor pendorong terjadinya perubahan dan cara meminimalkan faktor penghambat terjadinya perubahan. 
Dalam tulisan ini selanjutnya, analisis medan daya (Force Field Analysis) disingkat FFA. FFA bermanfaat memberikan gambaran permasalahan dan keadaankeadaan yang tidak dapat diubah dan memberikan analisis tentang cara menghapuskan hal-hal yang menghambat tercapainya tujuan.

Untuk mengetahui posisi progres implementasi $\mathrm{KPH}$, dilakukan analisis faktor strategis internal dan eksternal. Analisis faktor strategis internal merupakan prosedur pengolahan faktor-faktor strategis pada lingkungan internal (internal strategic factors analysis summary $=$ IFAS). Adapun analisis faktor strategis eksternal merupakan prosedur pengolahan faktor-faktor strategis pada lingkungan eksternal (external strategic factors analysis summary $=E F A S)$. Penilaian terhadap faktor internal dan eksternal dilakukan dengan memberikan pembobotan dan peringkat pada setiap faktor strategis dalam suatu tampilan tabel (Tabel IFAS - EFAS), menurut langkah-langkah sebagai berikut (lihat Lampiran 1):

a. Memasukkan faktor-faktor internal dan eksternal pada Tabel IFAS-EFAS kolom 1.

b. Memberikan bobot masing-masing faktor strategis pada kolom 2, dengan skala 1,0 (sangat penting) sampai dengan 0,0 (tidak penting). Semua bobot tersebut jumlahnya tidak melebihi dari skor total $=1,00$. Faktor-faktor itu diberi bobot berdasarkan pengaruh posisi strategis.

c. Memberikan peringkat pada kolom 3 untuk masing-masing faktor dengan skala mulai dari 4 (sangat kuat) sampai dengan 1 (lemah), berdasarkan pengaruh faktor tersebut terhadap kondisi bersangkutan.

d. Mengalikan bobot dengan peringkat untuk memperoleh nilai masing-masing faktor.

e. Menjumlahkan nilai masing-masing faktor (pada kolom 4). Nilai total ini menunjukan Nilai IFAS/EFAS, yang antara lain digunakan dalam penentuan posisi program pada Matriks Internal - Eksternal dari Wheelen.

\section{HASIL DAN PEMBAHASAN}

\section{A. Sejarah Pembangunan KPH Tana Toraja}

Kabupaten Tana Toraja memiliki kawasan hutan seluas 156.906 ha atau $48,94 \%$ dari luas wilayahnya. Kawasan tersebut terdiri dari hutan lindung seluas $138.101 \mathrm{ha}(88 \%)$ dan hutan produksi terbatas (HPT) seluas $18.805 \mathrm{ha}$ (12\%). Hutan pinus yang merupakan vegetasi andalan Tana Toraja menyebar di kawasan hutan lindung seluas 18.562 ha dengan potensi sekitar 16,7 juta $\mathrm{m}^{3}$ dan di kawasan hutan produksi terbatas seluas 10.201 ha dengan potensi sekitar 9,1 juta $\mathrm{m}^{3}$. Kawasan hutan produksi tersebar di beberapa wilayah kecamatan antara lain Kecamatan Simbuang, Kecamatan Saluputti-Bittuang dan Kecamatan Mengkendek (Badan Planologi Kehutanan, 2006). 
Keberadaan hutan pinus tersebut menjadi pertimbangan dalam rencana pembentukan unit wilayah KPH Tana Toraja, dengan klasifikasi perusahaan penghasil kayu dan getah pinus, di mana hasil hutan kayu pinus terutama dihasilkan dari kawasan hutan produksi, dan hasil hutan berupa getah pinus diperoleh pada hutan produksi dan hutan lindung.

Menyadari bahwa HPT yg ada sampai saat ini belum dikelola dengan baik dan untuk itu diperlukan suatu unit manajemen untuk mengelolanya, maka diterbitkanlah arahan pencadangan KPHP Sulsel melalui surat No.S.78/MenhutVII/Pu/2004 tanggal 11 Oktober 2004. Dalam surat tersebut HPT di Kabupaten Tana Toraja diarahkan sebagai satu Kesatuan Pengelolaan Hutan Produksi (KPHP) tersendiri dengan luasan 15.667,27 ha.

Pemda Kabupaten Tana Toraja menindaklanjuti penyusunan proposal dimaksud dengan pembahasan proposal KPHP Tana Toraja di Dephut. Berdasarkan Surat Kepala Pusat Pembentukan Wilayah Pengelolaan dan Perubahan Kawasan Hutan No. S.276/VII-Pw/S-PH/2005 perihal Proposal Teknis Pembentukan KPHP Kabupaten Tana Toraja dan Surat Kepala Badan Planologi No. S.398/VII-Pw/2005 tanggal 23 Mei 2005 perihal Pembentukan KPHP Kabupaten Tana Toraja, Pemda Tana Toraja menyusun Pembentukan KPHP Tana Toraja. Pada tanggal 29 Desember 2005 dilakukan konsultasi publik di Kabupaten Tana Toraja yang dihadiri parapihak. Pada tahun 2006 dibentuklah KPHP Tana Toraja dengan SK Bupati No. 2327/IX/2006 tanggal 23 September 2006, yang selanjutnya diteruskan ke Gubernur Sulsel sebagai unit KPHP Tana Toraja.

Pembangunan KPH Tana Toraja merupakan program Dinas Kehutanan dan Perkebunan Kabupaten Tana Toraja yang memiliki visi "terwujudnya pengelolaan kawasan hutan produksi yang lestari" dengan misi pemberdayaan masyarakat di dalam dan di sekitar kawasan hutan serta pengelolaan hutan secara partisipatif, yang bertujuan: mengelola hutan produksi secara efisien dan efektif; merumuskan strategi penataan hutan menuju pemantapan kawasan hutan; memproduksi hasil hutan kayu dan bukan kayu secara lestari; dan memberi keuntungan kepada masyarakat dan organisasi KPH agar dapat mandiri.

Pembentukan KPH Tana Toraja melalui proses: 1) Proses awal pembentukan $\mathrm{KPH}$ seluas $156.906 \mathrm{Ha}$ dimulai dengan pengelolaan kawasan hutan produksi seluas 18.805 Ha yang saat ini telah berproses untuk dikelola sebagai areal KPHP; 2) Selanjutnya akan dilakukan penyesuaian-penyesuaian ke arah pengelolaan seluruh kawasan hutan sebagai suatu unit KPH; dan 3) KPHP Tana Toraja, sesuai SK Bupati Tana Toraja, akan dikelola oleh UPTD dengan struktur organisasi disesuaikan kebutuhan, dan tetap melibatkan masyarakat setempat.

Dalam perencanaan pengelolaannya, KPH akan dibagi menjadi tiga wilayah Bagian Daerah Hutan (BDH) dengan pertimbangan homogenitas wilayah, terutama dari aspek fisik, sosial ekonomi, dan sebarannya. Wilayah I (BDH Saluputti) adalah 
wilayah yang terletak di sebelah utara, didominasi fungsi hutan lindung, medan berat, tingkat aksesibilitas rendah, tutupan lahan hutan alam, merupakan hulu dari hampir seluruh sungai yang ada di Tana Toraja. Wilayah II (BDH Mengkendek) adalah wilayah yang terletak di bagian tengah, didominasi hutan produksi bervegetasi pinus hasil reboisasi, beberapa lokasi memiliki medan yang lebih ringan, tingkat aksesibilitas lebih tinggi, dengan tutupan lahan banyak terdapat tegakan pinus hasil reboisasi, serta rawan perambahan. Wilayah III (BDH Bittuang) adalah wilayah yang terletak di sebelah selatan, didominasi lahan kritis, medan berat, aksesibilitas rendah, didominasi oleh hutan lindung. Merupakan hulu dari beberapa anak sungai yang ada. Pembentukan tiga wilayah $\mathrm{BDH}$ tersebut direncanakan diawali dengan pengelolaan hutan produksi, dengan pertimbangan telah ada sebelumnya pembentukan KPHP, serta untuk mendapatkan kondisi yang mapan terlebih dahulu dari hasil pengelolaan hutan produksi berupa getah dan kayu pinus. Gambaran potensi tegakan di Kecamatan Mengkendek yang menjadi titik mulai pembangunan KPH Tana Toraja, disajikan pada Tabel 1.

Untuk melaksanakan tugas/fungsi pengelolaan $\mathrm{KPH}$, akan dibentuk UPTD sebagaimana diatur dalam SK Bupati Tana Toraja. Bagan organisasi KPH Model Tana Toraja disajikan pada Gambar 1.

Konsep KPH Tana Toraja telah menjabarkan rencana tahap capaian sampai dengan peresmiannya pada tahun 2009, tetapi sampai saat ini belum dapat dilaksanakan. Tahap pembangunan KPHP, sebagaimana disajikan pada Tabel 2, mengalami "stagnasi" sejak tahun 2007.

Tabel 1. Potensi tegakan di hutan produksi terbatas Kecamatan Mengkendek Table 1. The potency of the stand in limited production forest in Mengkendek District

\begin{tabular}{|l|l|c|c|}
\hline \multirow{2}{*}{$\begin{array}{c}\text { Lokasi } \\
\text { (Location) }\end{array}$} & \multirow{2}{*}{$\begin{array}{c}\text { Jenis Tanaman } \\
\text { (Tree Species) }\end{array}$} & \multicolumn{2}{|c|}{$\begin{array}{c}\text { Potensi } \\
\text { (Potency) }\end{array}$} \\
\cline { 3 - 4 } & & $\begin{array}{c}\text { Volume } \\
(\text { Volume }), \mathrm{m}^{3} / \mathrm{ha}\end{array}$ & $\begin{array}{c}\text { Jumlah Pohon } \\
\text { (Number of trees), } \mathrm{N} / \mathrm{ha}\end{array}$ \\
\hline Tandotando I & Pinus & 59,96 & 166 \\
\hline Tandotando II & Pinus & 342,05 & 167 \\
\hline Pakala & Pinus & 115,31 & 111 \\
\hline
\end{tabular}

Sumber (Source): Data Primer diolah, 2009 (Primary Data, 2009) 


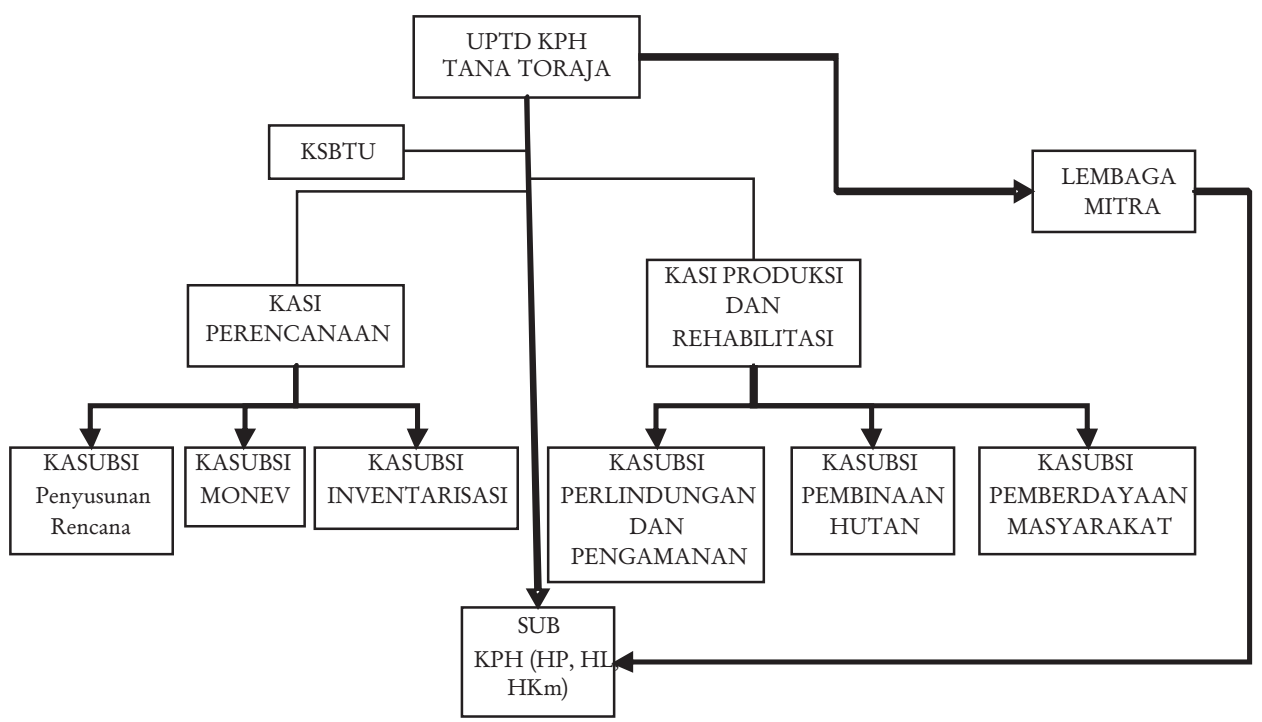

Gambar 1. Struktur organisasi pengelola KPH Model Tana Toraja Figure 1. Organisation chart of KPH Model of Tana Toraja

Analisis rancang bangun KPH Tana Toraja, sebagaimana dilaporkan Balai Penelitian Kehutanan Makassar (2008) menunjukkan beberapa hal, sebagai berikut:

- Konsep rancang bangun belum secara jelas mengakomodasi kepentingan masyarakat dalam pengelolaan dan juga belum menawarkan pelibatan investor (pihak swasta) dalam program kemitraan dalam pengelolaan hutan.

- Konsep rancang bangun belum mengemukakan rencana spesifik jangka panjang-menengah-pendek pengelolaan secara komprehensif dan sinergis.

- Konsep belum menyajikan wujud intitusi pengelola (kelembagaan) di lapang sebagai wadah kegiatan, SDM yang kompeten pada level manajerial, petugas lapang, dan masyarakat terlatih, serta mekanisme kerja antarinstansi terkait.

Hasil wawancara dengan Kepala Dinas Kehutanan dan Perkebunan Kabupaten Tana Toraja dan tokoh masyarakat dari LSM Walda, mengungkapkan bahwa sesungguhnya pemerintah daerah dan masyarakat merasakan tidak ada hambatan yang berarti di daerah dalam penyiapan pembangunan $\mathrm{KPH}$. Hal ini sejalan dengan komitmen parapihak di Kabupaten Tana Toraja dalam proses penyiapan pembangunan KPH. Hambatan yang dirasakan adalah lamanya proses yang harus ditempuh, mulai dari pengusulan konsep kepada gubernur pada tahun 2005 yang baru disetujui tahun 2007, dan selanjutnya diajukan ke Kementerian Kehutanan. Ringkasnya, dibutuhkan waktu yang cukup lama antara mulai 
penunjukan KPH Model di Kabupaten Tana Toraja sampai dengan proses penetapan oleh Menteri Kehutanan. Diharapkan payung hukum tersebut sudah ada sebelum berakhirnya masa jabatan bupati pada saat pengajuan. Dinyatakan oleh perangkat dinas kehutanan kabupaten sebagai hal yang tidak mudah dalam memperoleh dukungan bupati dan DPRD terhadap KPHP, khususnya persiapan institusi pengelola dan persetujuan dana operasionalnya.

Tabel 2. Rencana tahap pembangunan KPH Model Tana Toraja

Table 2. The plan of KPH Model of Tana Toraja's development phases

\begin{tabular}{|c|c|c|c|c|}
\hline 2005 & 2006 & 2007 & 2008 & 2009 \\
\hline $\begin{array}{l}\text { Rancang } \\
\text { bangun KPH } \\
\text { P Tana Toraja } \\
\text { Inisiasi Dinas } \\
\text { Kehutanan }\end{array}$ & $\begin{array}{l}\text { Pembentukan } \\
\text { KPHP Tana } \\
\text { Toraja } \\
\text { Pengesahan } \\
\text { KPHP Tana } \\
\text { Toraja di } \\
\text { Kabupaten }\end{array}$ & $\begin{array}{l}\text { Pengesahan } \\
\text { KPHP Tana } \\
\text { Toraja di } \\
\text { Propinsi } \\
\text { Penetapan } \\
\text { KPH Tana } \\
\text { Toraja } \\
\text { MENHUT } \\
\text { Penyiapan } \\
\text { organisasi } \\
\text { pengelola } \\
\text { KPH Tana } \\
\text { Toraja } \\
\text { Penyusunan } \\
\text { Action Plan } \\
\text { KPH Tana } \\
\text { Toraja }\end{array}$ & $\begin{array}{l}\text { Penataan } \\
\text { wilayah KHP } \\
\text { menjadi unit } \\
\text { unit BDH } \\
\text { Re-evaluasi } \\
\text { fungsi kawasan. } \\
\text { Menyusun } \\
\text { perencanaan } \\
\text { pengelolaan } \\
\text { wilayah KPH } \\
\text { dan BDH } \\
\text { Penyiapan } \\
\text { mekanisme cost } \\
\text { sharing } \\
\\
\text { Penyiapan } \\
\text { masyarakat } \\
\text { (kelembagaan, } \\
\text { kapasitas) }\end{array}$ & $\begin{array}{l}\text { Peresmian KPH } \\
\text { Tana Toraja oleh } \\
\text { MENHUT } \\
\text { Penyiapan } \\
\text { kapasitas dan } \\
\text { kelembagaan } \\
\text { masyarakat } \\
\text { Penyiapan SDM } \\
\text { pada level } \\
\text { manajerial dan } \\
\text { lapangan dengan } \\
\text { berbasis pada } \\
\text { potensi lokal. } \\
\text { Memberikan } \\
\text { berbagai pelatihan } \\
\text { kepada } \\
\text { masyarakat } \\
\text { setempat untuk } \\
\text { terlibat di dalam } \\
\text { pengelolaan KPH } \\
\text { Mengembangkan } \\
\text { pola silvikultur } \\
\text { yang tepat sesuai } \\
\text { dengan } \\
\text { karakteristik } \\
\text { wilayah Tana } \\
\text { Toraja }\end{array}$ \\
\hline
\end{tabular}

Sumber (Source): Badan Planologi Kehutanan, 2006 (Forestry Planning Agency, 2006) 
Menyiasati lamanya proses terbitnya payung hukum, proses persiapan di bawah (pemerintah daerah bersama masyarakat) tetap berjalan, yaitu:

1. Perencanaan program bersama masyarakat, seperti sosialisasi KPH selama 6 (enam) bulan terakhir 2009 di Kecamatan Mengkendek dan sekitarnya, khususnya sosialisasi tentang komposisi tanaman yang terdiri dari tanaman kehutanan, multipurpose treespecies (MPTS), dan tanaman sela.

2. Penguatan kelembagaan masyarakat yang akan disinergikan dengan peran UPTD (eselon III) KPH. Dalam hal ini, tidak dibentuk kelompok baru, tapi diaktifkan kembali kelompok lama yang sudah ada sejak 1980-an. Dimulai dengan 3 (tiga) KTH pada 3 (tiga) lembang (desa) di Kecamatan Mengkendek yang melibatkan $\pm 150 \mathrm{KK}$, yakni KTH Sipatuo di Lembang Pattengko, KTH Tando-tando di Lembang Pakala, dan KTH Dada di Lembang Rante Dada. Terbukanya peluang kemitraan dalam pengelolaan KPH: masyarakat (upah kerja, nilai kayu), pengusaha (bahan baku terjamin), pemerintah (kinerja sebagai pelaksanaan TUPOKSI), dan jejaring kerja lainnya sebagai suatu social capital.

3. Persiapan wilayah kelola (menunggu payung hukum Kepmenhut) berupa kawasan hutan produksi seluas \pm 18.000 hektar, mencakup 3 (tiga) hamparan: Mengkendek, Masila, dan Simbuang. Secara administratif, wilayah ini termasuk dalam 4 (empat) wilayah kecamatan, yaitu: Saluputti, Mappa, Mengkendek, dan Gandasil.

Sosialisasi lebih intensif tentang konsep KPH dan peraturan perundangan yang terkait sangat dibutuhkan untuk menyamakan persepsi dan pemahaman parapihak. Pemerintah daerah, terutama kabupaten, perlu diberikan ruang dan peran yang lebih luas mulai dari proses pembentukan $\mathrm{KPH}$ sampai pada penyusunan rencana pengelolaannya. Belum adanya pelibatan parapihak primer (kunci) dalam pembuatan rancang-bangun pembangunan konsep KPH secara aktif di tingkat masyarakat, investor (pengusaha), dan lembaga adat yang ada di daerah setempat akan menyebabkan terhambatnya implementasi KPH di lapang. Faktor-faktor penghambat pembangunan $\mathrm{KPH}$ pada umumnya terkait dengan aspek kebijakan yang belum konsisten dan sinergis, aspek sosial-ekonomi-budaya yang beragam, aspek kelembagaan dan pendanaan operasional $\mathrm{KPH}$.

\section{B. Keadaan Sosial, Ekonomi dan Budaya}

Wilayah Kabupaten Tana Toraja terbagi atas 32 wilayah masyarakat adat yang dikelompokkan atas tiga pemerintahan adat utama yaitu pemerintahan adat Tondok Dipuangngi, Tondok Dima'dikai dan Tondok Diambei. Setiap pemerintahan adat memiliki aturan-aturan yang mengatur kehidupan sosial kemasyarakatan, hukum, keamanan dan pemanfaatan sumberdaya alam. Oleh karena itu, pengelolaan KPH Tana Toraja perlu mengakomodasi nilai-nilai dan kearifan lokal. 
Kelembagaan masyarakat adat sebagai salah satu wadah pelestarian nilai-nilai dan kearifan lokal telah dibentuk di Kecamatan Mengkendek. Hasil wawancara dengan tokoh masyarakat menunjukkan bahwa wilayah adat tersebut merupakan kelanjutan dari wilayah adat Borisan Rinding yang terbentuk pada sekitar tahun 1700-an sebagai hasil kesepakatan antara Puang Landek Palodang ke IV ( Raja) Sangalla dengan Pasapangan yang mewakili rakyat ( To buda). Wilayah tersebut dimaksudkan sebagai Borisan Rinding (buffer zone/daerah khusus ) dari intervensi pihak luar.

Ketika masa DI/TII, wilayah tersebut hancur dan ditinggalkan penduduknya yang pergi mengungsi. Tahun 1961 ketika keamanan sudah pulih kembali maka diadakan lagi kombongan kalua Borisan Rinding yang dihadiri oleh ahli waris Puang Landek yaitu Puang Popang (WP Sombolinggi), Puang Paliwang Tandi Langi dan Puang A.L.Londong Allo bersama tokoh masyarakat dan Toparenge, yang menghasilkan kesepakatan untuk membangun kembali kelembagaan Adat Borisan Rinding.

Saat ini Kelembagaan Adat Borisan Rinding dan Tampo tetap menjadi payung dari lembaga (yang lazim disebut kelompok tani) yang terbentuk di lembang dan kelurahan. Kesamaan kepentingan terhadap kawasan hutan tersebut telah mengarahkan masyarakat untuk membentuk kelompok yang sudah dimulai sejak tahun 2000. Saat ini telah terdapat 16 kelompok tani hutan (KTH) dengan jumlah anggota 464 orang yang tersebar pada 5 (lima) lembang, yakni Pakala, Rante Dada, Pa'tengko, Buntu Datu, dan Simbuang. Jumlah seluruh anggota KTH 464 orang terdiri dari 365 laki-laki (79\%) dan 99 perempuan (21\%). Seluruh kelompok telah mempunyai AD/ART serta susunan pengurus dan keanggotaan.

Berkaitan dengan program pemanfaatan hasil hutan pinus, masyarakat Borisan Rinding dan Tampo tetap berkomitmen melestarikan hutan yang merupakan hasil reboisasi dan penghijauan tahun 1972 - 1974 dan menjaganya agar tidak ada perubahan fungsi hutan untuk tujuan-tujuan lain. Untuk itu, dengan adanya sosialisasi dari program KPHP maka masyarakat sangat mendukung dan akan menjadi benteng terdepan pembangunan kehutanan yang berbasis masyarakat.

Jumlah penduduk Kabupaten Tana Toraja sebanyak 394.141 jiwa dengan persentase usia produktif $47,35 \%$ di mana sebagian besar (56,43\%) bergiat di sektor pertanian. Tingkat ketergantungan masyarakat terhadap hasil hutan kayu maupun non kayu sangat tinggi dalam menopang pendapatan dari usaha tani di dalam dan di sekitar kawasan hutan, baik berupa kayu pinus, uru/cempaka, dan cemara gunung. Pendapatan rata-rata penduduk di dalam dan sekitar kawasan hutan bervariasi dari Rp 1.200.000-Rp 1.500.000/bulan.

Terwujudnya KPH Tana Toraja akan bermanfaat bagi semua parapihak, yakni bagi pemerintah pusat berupa penerimaan PSDH, bagi pemerintah daerah adalah penerimaan $\mathrm{PAD}$, dan bagi masyarakat adalah peluang peningkatan 
pendapatan melalui pengelolaan hutan secara legal-formal. Dengan terwujudnya $\mathrm{KPH}$, pengelolaan kawasan hutan diharapkan dapat mewujudkan kelestarian hutan dan kesejahteraan masyarakat. Parapihak pun telah mengambil peran sesuai kapasitas masing-masing. Peran dalam penguatan kelembagaan masyarakat dilakukan oleh LSM WALDA dengan melibatkan mantan koordinator penyuluh kehutanan kecamatan, didampingi oleh aparat dinas terkait.

\section{Beberapa Faktor dalam Implementasi KPH Tana Toraja}

Hasil wawancara dan diskusi dengan parapihak pada forum FGD (Focus Group Discussion), menyepakati beberapa faktor dalam proses implementasi KPH di Kabupaten Tana Toraja. Faktor-faktor tersebut terdapat pada ketiga parapihak, yakni pemerintah, masyarakat, dan dunia usaha (private sector) dengan cakupan yang luas meliputi regulasi, program instansi, kapasitas pelaku, potensi sumber daya hutan, minat investor, pola tanam, kelembagaan, permintaan dan persediaan komoditas, potensi konflik, dan sebagainya. Faktor-faktor tersebut dikelompokkan dalam faktor pendorong dan faktor penghambat yang disajikan pada Tabel 3 .

Dari Tabel 3 diketahui bahwa faktor pendorong terwujudnya implementasi $\mathrm{KPH}$ sebagian besar datang dari masyarakat dan jaringannya, termasuk interaksinya dengan kawasan sumber daya hutan di sekitarnya. Selanjutnya disusul oleh jajaran daerah, baik eksekutif maupun legeslatif. Sekalipun demikian, posisi kunci berada pada pemerintah daerah, dalam hal ini bupati dan DPRD sebagai penentu kebijakan. Selain itu, faktor pemerintah daerah ini menjadi sangat penting, karena dibatasi oleh periode waktu tertentu. Penguatan kelembagaan dan kapasitas masyarakat oleh LSM pendamping secara berkelanjutan bersama jaringannya, diharapkan dapat menjadi gerakan masyarakat untuk mewujudkan $\mathrm{KPH}$ dan senantiasa mengingatkan siapapun yang duduk di pemerintahan daerah tentang program dimaksud. 
Tabel 3. Identifikasi faktor pendorong dan faktor penghambat implementasi KPH Tana Toraja

Table3. The identification of driving factors and restraining factors in the implementation of KPH Tana Toraja

\begin{tabular}{|c|c|}
\hline $\begin{array}{l}\text { Faktor pendorong } \\
\text { (Driving factors) }\end{array}$ & $\begin{array}{l}\text { Faktor penghambat } \\
\text { (Restraining factors) }\end{array}$ \\
\hline - Kesiapan masyarakat mendukung program & $\begin{array}{l}\text { - Kekhawatiran sebagian masyarakat akan } \\
\text { pergeseran peran dalam pengelolaan SDH. }\end{array}$ \\
\hline $\begin{array}{l}\text { - Kebutuhanmasyarakat terhadap lahan } \\
\text { garapan secara legalformal. }\end{array}$ & $\begin{array}{l}\text { - Kurangnya pemahaman sebagian } \\
\text { masyarakat tentang fungsi hutan. }\end{array}$ \\
\hline $\begin{array}{l}\text { - Kehadiran tokoh masyarakat yang visioner } \\
\text { dalam penyadaran masyarakat. }\end{array}$ & $\begin{array}{l}\text { - Pemukiman yang tumbuh di dalam dan } \\
\text { sekitar kawasan hutan. }\end{array}$ \\
\hline - Motivasimasyarakat terhadap ekonomi & $\begin{array}{l}\text { - Adanya SPPT atas lahan kawasan hutan } \\
\text { pada sebagian masyarakat. }\end{array}$ \\
\hline - Motivasi masyarakat terhadap ekologi. & - Kurangnya modal masyarakat. \\
\hline $\begin{array}{l}\text { - Sudah ada draf awal institusi pengelola } \\
\text { KPH. }\end{array}$ & - Kurangnya sarana prasarana pendukung. \\
\hline $\begin{array}{l}\text { - Kesiapan dims kehutanan sebagaileading } \\
\text { sectorimplementasi KPH. }\end{array}$ & $\begin{array}{l}\text { - Belum ada dasar hukum yang memayungi } \\
\text { operasionalisasi program KPH Toraja. }\end{array}$ \\
\hline $\begin{array}{l}\text { - Dukungan Bupati Toraja dan DPRD } \\
\text { periode berjalan terhadap program KPH. }\end{array}$ & $\begin{array}{l}\text { - Lamanya menunggu proses penerbitan } \\
\text { keputusan Menhutentang KPH Toraja. }\end{array}$ \\
\hline $\begin{array}{l}\text { - Potensi SDH (hutan pinus) dan partisipasi } \\
\text { masyarakat dalam pengelolaannya. }\end{array}$ & $\begin{array}{l}\text { - Banyak program Dephut yang perlu } \\
\text { ditindaklanjuti daerah secara bersamaan. }\end{array}$ \\
\hline - Adanya LSM pendamping (WALDA). & $\begin{array}{l}\text { - Fluktuasi harga komoditi yang } \\
\text { dibudidayakan masyarakat }\end{array}$ \\
\hline $\begin{array}{l}\text { - Telah ada investor yang berminat untuk } \\
\text { bermitra. }\end{array}$ & $\begin{array}{l}\text { - Kurangnya espon lembaga keuangan } \\
\text { terhadap usaha masyarakat di sektor } \\
\text { kehutanan/pertanian. }\end{array}$ \\
\hline
\end{tabular}

Sumber (Source): Data primer diolah, 2009 (Primary data, 2009)

Adapun faktor penghambat implementasi KPH di Kabupaten Tana Toraja ada yang datang dari masyarakat, pemerintah pusat, dan kondisi sumber daya hutan. Hambatan dari masyarakat secara bertahap diharapkan dapat dikurangi dan dihilangkan melalui penguatan kelembagaan dan kapasitas masyarakat. Demikian halnya, kondisi sumber daya hutan yang pengelolaannya menjadi tugas dan tanggung jawab instansi terkait di daerah, juga diharapkan dapat diatasi melalui program Dinas Kehutanan dan Perkebunan Tana Toraja. Namun, yang menyangkut domain pemerintah pusat, sebagaimana terungkap dalam wawancara dengan Kepala Dinas Kehutanan dan Perkebunan Tana Toraja, pemerintah daerah hanya menunggu dan menindaklanjuti apa yang sudah diperintahkan. 


\section{Analisis faktor strategis eksternal dan internal}

Untuk mengetahui seberapa besar pengaruh faktor-faktor yang dipaparkan sebelumnya berpengaruh dalam implementasi KPH di Kabupaten Tana Toraja, maka perlu dilakukan analisis EFAS dan IFAS yang prosedurnya disajikan pada Bab Metode Penelitian. Hasil analisis disajikan pada Tabel 4. Faktor-faktor yang termasuk kategori peluang dan ancaman digabungkan sebagai faktor strategis eksternal dan melalui diskusi masing-masing faktor ditentukan bobotnya atau porsinya terhadap keseluruhan. Misalnya dalam kasus pada Tabel 4 terdapat 9 (sembilan) faktor, apakah bobot atau porsi faktor merupakan 1/9, 2/9, atau 3/9, dan seterusnya dari keseluruhan faktor. Selanjutnya, nyatakan bobot dalam desimal. Sedangkan peringkat ditentukan berdasarkan tingkat pengaruh faktor terhadap program yang dikembangkan. Dalam kasus ini digunakan 4 (empat) peringkat, yakni 1 mewakili lemah, 2 rata-rata, 3 kuat, dan 4 sangat kuat. Peringkat ditentukan melalui diskusi, disarankan merupakan pertimbangan profesional (professional judgement). Untuk mendapatkan nilai masing-masing faktor, kalikan bobot dengan peringkatnya. Selanjutnya, jumlahkan nilai masing-masing faktor untuk memperoleh nilai EFAS.

Tabel 4. Ikhtisar analisis faktor strategis eksternal

Table 4. External strategicfactors analysis summary (EFAS)

\begin{tabular}{|c|c|c|c|}
\hline $\begin{array}{l}\text { Faktor-faktor strategis eksternal } \\
\text { (External strategic factors) }\end{array}$ & $\begin{array}{l}\text { Bobot } \\
\text { Quality }\end{array}$ & $\begin{array}{l}\text { Peringkat } \\
\text { (Ranking) }\end{array}$ & $\begin{array}{l}\text { Nilai } \\
\text { (Score) }\end{array}$ \\
\hline $\begin{array}{l}\text { Peluang } \\
\text { - Dukungan Bupati Toraja dan DPRD periode berjalan } \\
\text { terhadap program KPH. }\end{array}$ & 0,17 & 4 & 0,68 \\
\hline $\begin{array}{l}\text { - Potensi SDH (hutan pinus) dan partisipasi masyarakat dalam } \\
\text { pengelolaannya. }\end{array}$ & 0,10 & 1 & 0,10 \\
\hline - Adanya LSM pendamping (WALDA). & $0 \times 12$ & 2 & $0 ; 24$ \\
\hline $\begin{array}{l}\text { - Minat investor untuk bermitra dengan masyarakat calon } \\
\text { pengelola KPH. }\end{array}$ & 0,14 & 3 & 0,42 \\
\hline Ancaman & & & \\
\hline $\begin{array}{l}\text { - Belum ada dasar hukum yang memayungi operasionalisasi } \\
\text { program KPH. }\end{array}$ & 0,13 & 4 & 0,52 \\
\hline $\begin{array}{l}\text { - Lamanya proses penerbitan keputusan Menteri Kehutanan } \\
\text { tentang KPH. }\end{array}$ & 0,10 & 2 & 0,20 \\
\hline $\begin{array}{l}\text { - Program Dephut yang perlu ditindaklanjuti daerah dalam } \\
\text { waktu yang sama. }\end{array}$ & 0,12 & 4 & 0,48 \\
\hline - Fluktuasi harga komoditi yang dibudidayakan masyarakat. & 0,07 & 1 & 0,07 \\
\hline $\begin{array}{l}\text { - Respon lembaga keuangan terhadap usaha masyarakat } \\
\text { sektor kehutanan. }\end{array}$ & 0,05 & 1 & 0,05 \\
\hline Jumlah (Total) & 1,00 & & 2,76 \\
\hline
\end{tabular}

Sumber (Source): Data Primer diolah, 2009 (Primary Data, 2009) 
Sebagaimana prosedur dalam memperoleh nilai EFAS, demikian pula halnya untuk analisis IFAS, yang hasilnya disajikan pada Tabel 5. Jika biaya dan waktu cukup tersedia, dimungkinkan untuk melakukan diskusi lebih luas dengan melibatkan lebih banyak parapihak dalam menyepakati faktor-faktor pengaruh eksternal dan internal dalam hal jumlah, bobot, dan peringkatnya.

Pada Tabel 4 dapat dilihat peringkat setiap faktor eksternal, baik yang merupakan peluang maupun ancaman dalam implementasi KPH di Kabupaten Tana Toraja. Peringkat tersebut merupakan hasil rumusan dalam FGD yang dihadiri para pemangku kepentingan. Faktor peluang dengan peringkat tertinggi adalah dukungan Bupati Tana Toraja dan DPRD periode berjalan terhadap program $\mathrm{KPH}$. Pada era otonomi daerah, peran bupati yang didukung penuh oleh DPRD dipandang sebagai faktor kunci dalam keberlangsungan suatu program di daerah. Namun, faktor ini memiliki keterbatasan karena adanya batasan periode jabatan bupati dan anggota DPRD, bila dikaitkan dengan faktor eksternal lainnya, yakni lamanya proses penerbitan keputusan Menteri Kehutanan tentang KPH.

Dukungan bupati dan DPRD akan menjadi tidak efektif bila keputusan menteri tidak juga terbit. Pada saat penelitian ini dilaksanakan Dinas Kehutanan dan Perkebunan Kabupaten Tana Toraja belum memiliki dasar hukum yang memayungi operasionalisasi program KPH. Bila program dimaksud tidak dapat terlaksana sampai dengan berakhirnya masa jabatan bupati dan anggota DPRD periode sekarang, maka dapat dinyatakan bahwa proses akan dimulai dari awal lagi untuk mendapatkan dukungan bupati dan DPRD periode yang akan datang. Hal ini dapat menghambat pencapaian program lainnya, mengingat program kementerian yang perlu segera ditindaklanjuti oleh daerah, bukan hanya KPH.

Dampak lainnya bila program KPH tertunda-tunda adalah daerah akan kehilangan kesempatan dalam menangkap minat investor yang akan bermitra dengan masyarakat anggota kelompok yang mengelola lahan KPH. Selain itu, juga akan menurunkan semangat masyarakat yang selama ini sudah dibina melalui program pendampingan dari LSM setempat.

Peringkat faktor-faktor strategis internal, baik yang bersifat kekuatan maupun kelemahan dapat dilihat pada Tabel 5. Peringkat faktor-faktor kekuatan berkisar dari rata-rata sampai dengan sangat kuat. Kebutuhan masyarakat akan lahan garapan secara legal formal dan hadirnya tokoh masyarakat yang visioner dalam penyadaran masyarakat merupakan faktor kekuatan yang perlu diperhatikan. Peran tokoh visioner diperlukan dalam penyadaran masyarakat dalam mendukung program $\mathrm{KPH}$ yang akan memberi ruang kepada masyarakat untuk menggarap lahan hutan secara legal formal. Dukungan parapihak, termasuk masyarakat sekitar hutan, akan meringankan tugas instansi terkait yakni dinas kehutanan kabupaten sebagai leading sector, khususnya dalam mempersiapkan institusi pengelola KPH. 
Pada Tabel 5 dapat dilihat pula peringkat faktor-faktor kelemahan yang berkisar dari lemah sampai dengan sangat kuat. Adanya SPPT atas lahan kawasan hutan yang dijumpai pada sebagian masyarakat merupakan dampak dari tumbuhnya pemukiman di dalam dan sekitar kawasan hutan. Minat masyarakat untuk dapat menggarap lahan hutan secara legal formal melalui program $\mathrm{KPH}$, perlu disikapi dengan mempercepat proses implementasi $\mathrm{KPH}$.

Faktor-faktor strategis eksternal bukanlah faktor yang berdiri sendiri, melainkan saling berkaitan satu dengan yang lain. Pada Tabel 4 dapat dilihat jumlah dari nilai faktor-faktor strategis eksternal atau EFAS sebesar 2,76. Demikian pula halnya dengan faktor-faktor strategis internal. Pada Tabel 5 dapat dilihat jumlah dari nilai faktor-faktor strategis internal atau IFAS sebesar 2,92.

Berdasarkan model matriks internal-eksternal dari Wheelen (1995) dalam Rangkuti (2008), dengan jumlah nilai IFAS $=2,92$ dan nilai EFAS $=2,76$ (dilihat pada Lampiran 1) maka pembangunan KPH Tana Toraja berada pada kategori "growth-stability". Ini berarti bahwa strategi yang sesuai adalah konsentrasi melalui integrasi horizontal dalam posisi stabil. Strategi ini termasuk dalam strategi pertumbuhan dengan cara memperluas kegiatan di masyarakat dan mengembangkan jaringan informasi dan komunikasi antardaerah yang memiliki program $\mathrm{KPH}$.

Tabel 5. Ikhtisar analisis faktor strategis internal

Table 5. Internal strategic factors analysis summary (IFAS)

\begin{tabular}{|c|c|c|c|}
\hline $\begin{array}{l}\text { Faktor-faktor strategis internal } \\
\text { (Internal strategic factors) }\end{array}$ & $\begin{array}{c}\text { Bobot } \\
\text { (Quality) }\end{array}$ & $\begin{array}{l}\text { Peringkat } \\
\text { (Ranking) }\end{array}$ & $\begin{array}{c}\text { Nilai } \\
\text { (Score) }\end{array}$ \\
\hline \multicolumn{4}{|l|}{ Kekuatan } \\
\hline - Kesiapan masyarakat mendukung programKPH. & 0,11 & 3 & 0,33 \\
\hline $\begin{array}{l}\text { - Kebutuhan masyarakat terhadap lahan garapan secara legal } \\
\text { - formal. Kehadiran tokoh masyarakat yang visioner dalam }\end{array}$ & 0,09 & 2 & 0,18 \\
\hline penyadaran masyarakat. & 0,04 & 2 & 0,08 \\
\hline - Motivasi masyarakat terhadap ekonomi. & 0,06 & 3 & 0,18 \\
\hline - Motivasimasyarakat terhadap ekologi. & 0,07 & 3 & 0,21 \\
\hline $\begin{array}{l}\text { - Sudah ada draf awal institusi pengelola KPH. } \\
\text { - Kesiapan dinas kehutanan sebagai leading sector }\end{array}$ & 0,11 & 4 & 0,44 \\
\hline implementasi KPH. & 0,13 & 4 & 0,52 \\
\hline \multirow{3}{*}{$\begin{array}{l}\text { Kelemahan } \\
\text { - Sebagian masyarakat khawatirkan pergeseran peran dalam } \\
\text { pengelolaan SDH } \\
\text { - Sebagian masyarakat kurang memahami fungsi dan manfaat } \\
\text { hutan. }\end{array}$} & & & \\
\hline & 0,07 & 1 & 0,07 \\
\hline & 0,06 & 1 & 0,06 \\
\hline \multirow{2}{*}{$\begin{array}{l}\text { - Pemukiman yang tumbuh di dalam dan sekitar kawasan hutan. } \\
\text { - Adanya SPPT atas lahan kawasan hutan pada sebagian } \\
\text { masyarakat. }\end{array}$} & 0,09 & 3 & 0,27 \\
\hline & 0,11 & 4 & 0,44 \\
\hline - Kurangnya modal masyarakat. & 0,04 & 2 & 0,08 \\
\hline - Kurangnya sarana prasarana pendukung. & 0,02 & 3 & 0,06 \\
\hline Jumlah(Total) & 1,00 & & 2,92 \\
\hline
\end{tabular}

Sumber (Source) : Data primer diolah, 2009 (Primary data processed, 2009) 


\section{Analisis medan daya (Force field analysis $=$ FFA)}

Singer (2009) yang telah menerapkan analisis FFA secara partisipatif menyatakan bahwa diskusi kelompok diperlukan untuk merumuskan: (a) cara memperkuat faktor pendorong, dan (b) cara meminimalkan faktor penghambat terjadinya perubahan. Dengan mengikuti langkah-langkah analisis FFA, faktor pendorong dan faktor penghambat dapat ditampilkan sebagaimana Gambar 2.

Pada Gambar 2 faktor pendorong dan faktor penghambat diperhadapkan satu sama lain dalam pengaruhnya terhadap program atau kegiatan yang dilaksanakan, yakni implementasi KPH di Kabupaten Tana Toraja. Besarnya pengaruh faktor digambarkan sebagai anak panah dengan panjang berbeda sesuai dengan peringkat dalam analisis EFAS-IFAS, mulai dari lemah yang diberi nilai 1 sampai dengan sangat kuat yang diberi nilai 4. Faktor pendorong merupakan gabungan dari faktor strategis eksternal peluang dan faktor strategis internal kekuatan. Total nilai faktor pendorong diperoleh dari penjumlahan peringkat faktor pendorong, sebesar 31. Adapun faktor penghambat merupakan gabungan dari faktor strategis eksternal ancaman dan faktor strategis internal kelemahan. Total nilai faktor penghambat diperoleh dari penjumlahan peringkat faktor penghambat, sebesar 26. Total nilai faktor pendorong yang lebih besar daripada total nilai faktor penghambat menunjukkan bahwa implementasi KPH di Kabupaten Tana Toraja dapat berjalan.

\begin{tabular}{|c|c|}
\hline $\begin{array}{l}\text { Faktor pendorong } \\
\text { (Driving factors) }\end{array}$ & $\begin{array}{l}\text { Faktor penghambat } \\
\text { (Restraining factors) }\end{array}$ \\
\hline Internal & Internal \\
\hline $\begin{array}{l}\text { - Kesiapan masyarakat mendukung program. } \\
\text { - Kebutuhan masyarakat akan lahan garapan. } \\
\text { - Kehadiran tokoh masyarakat yang visioner. } \\
\text { - Motivasi masyarakat terhadap ekonomi. } \\
\text { - Motivasi masyarakat terhadap ekologi. } \\
\text { - Sudah ada draf awal institusi pengelola KPH. } \\
\text { - Kesiapan Dishutbun sebagadeading sector. }\end{array}$ & $\begin{array}{l}\text { - Pergeseran peran dalam pengelolaan SDH. } \\
\text { - Kurangnya pemahaman fungsi \& manfaat hutan. } \\
\text { - Pemukiman tumbuh di dalam kawasan hutan. } \\
\text { - Adanya SPPT atas lahan kawasan hutan. } \\
\text { - Kurangnya modal masyarakat. } \\
\text { - Kurangnya sarana prasarana pendukung. }\end{array}$ \\
\hline Eksternal & Eksternal \\
\hline $\begin{array}{l}\text { - Dukungan Bupati Toraja dan DPRD. } \\
\text { - Potensi SDH (hutan pinus). } \\
\text { - Adanya LSM pendamping (WALDA). } \\
\text { - Minat investor untuk bermitra. }\end{array}$ & $\begin{array}{l}\text { - Belum ada dasar hukum operasionalisasi. } \\
\text { - Lamanya proses penerbitan kepmenhut - KPH. } \\
\text { - Program Dephut yang beruntun. } \\
\text { - Fluktuasi harga komoditi yang dibudidayakan. } \\
\text { - Respon lembaga keuangan. }\end{array}$ \\
\hline
\end{tabular}

Gambar2. Ilustrasi pengaruh faktor pendorong dan faktor penghambat terhadap implementasi KPH Tana Toraja

Figure 2. The illustration of driving and restraining factors to the implementation of KPH Tana Toraja 
Ukuran gambar anak panah pada Gambar 2 yang mewakili kekuatan faktor pendorong dan faktor penghambat bervariasi dari yang pendek (lemah), sedang (rata-rata), sampai dengan panjang (sangat kuat). Semakin kuat faktor pendorong akan semakin melemahkan pengaruh faktor penghambat, sehingga semakin besar peluang suatu program dapat dilaksanakan. Oleh karena itu, diskusi para pihak terkait (stakeholder) dalam FGD lebih diarahkan kepada memperkuat faktor pendorong yang berada pada posisi lemah dan memperkecil pengaruh faktor penghambat yang berada pada posisi kuat, dengan tetap memperhatikan dinamika faktor lainnya.

Berdasarkan Gambar 2 faktor pendorong yang perlu diperkuat posisinya adalah kebutuhan masyarakat akan lahan garapan, kehadiran tokoh masyarakat yang visioner, potensi hutan pinus, dan peran LSM pendamping. Keempat faktor pendorong tersebut saling berkaitan. Tokoh masyarakat visioner yang juga merupakan pendiri LSM dimaksud, melalui program pendampingannya secara terus-menerus membangun kesadaran masyarakat tentang pentingnya menjaga sumberdaya hutan pinus di Tana Toraja. Di samping itu, kebutuhan masyarakat akan lahan garapan tetap difasilitasi agar memperoleh akses secara legal formal melalui pembangunan KPH. Adapun faktor penghambat yang perlu diperkecil pengaruhnya adalah pemukiman yang berkembang di dalam kawasan hutan, penerbitan SPPT atas lahan kawasan hutan, penyiapan sarana prasarana pendukung kegiatan KPH, penerbitan dasar hukum operasionalisasi KPH di daerah, dan tindak lanjut program pemerintah pusat di sektor kehutanan oleh daerah dalam waktu yang sama. Penguatan faktor pendorong, khususnya yang terkait penyadaran masyarakat diharapkan dapat memperkecil faktor penghambat yang datang dari masyarakat. Sedangkan yang terkait dengan tugas pokok instansi, dapat dilakukan dengan memperluas kegiatan di masyarakat serta mengembangkan jaringan informasi dan komunikasi dengan daerah lain yang juga memiliki program $\mathrm{KPH}$.

\section{KESIMPULAN DAN SARAN}

\section{A. Kesimpulan}

1. Rencana pembangunan KPH Tana Toraja berhadapan dengan sejumlah issu, baik bersifat mendorong maupun menghambat implementasi. Pembangunan KPH Tana Toraja berada pada kategori "growth-stability", maka strategi yang sesuai adalah konsentrasi melalui integrasi horizontal dengan cara memperluas kegiatan di masyarakat dan mengembang-kan jaringan informasi dan komunikasi antardaerah yang memiliki program KPH.

2. Strategi implementasi KPH Tana Toraja yang dapat dikembangkan oleh Dinas Kehutanan dan Perkebunan Kabupaten Tana Toraja adalah memperkuat faktor 
pendorong internal (kebutuhan masyarakat akan lahan garapan dan kehadiran tokoh masyarakat yang visioner) dan faktor pendorong eksternal (potensi hutan pinus dan peran LSM pendamping), serta memperkecil pengaruh faktor penghambat internal (pemukiman yang berkembang di dalam kawasan hutan, penerbitan SPPT atas lahan kawasan hutan, dan penyiapan sarana prasarana pendukung kegiatan $\mathrm{KPH}$ ), dan faktor penghambat eksternal (penerbitan dasar hukum operasionalisasi KPH di daerah dan tindak lanjut program pemerintah pusat di sektor kehutanan oleh daerah dalam waktu yang sama).

\section{B. Saran}

1. Kesiapan Dinas Kehutanan dan Perkebunan Kabupaten Tana Toraja sebagai leading sector dalam implementasi $\mathrm{KPH}$, perlu didukung dengan penyusunan agenda yang mencakup strategi pada butir 1 dan 2 dalam kesimpulan di atas.

2. Parapihak pembangunan KPH di Tana Toraja perlu lebih menyuarakan program KPH sebagai satu gerakan masyarakat, baik melalui media massa maupun elektronik agar mendapat dukungan luas dalam percepatan implementasinya.

3. Perlu penataan regulasi pada institusi pemerintah pusat, khususnya tata waktu dalam pencapaian tahap-tahap kegiatan, agar pembangunan KPH dapat tercapai sesuai waktu yang direncanakan.

\section{UCAPAN TERIMA KASIH}

Ucapan terima kasih dan penghargaan disampaikan kepada Bapak Dr. Haryatno Dwiprabowo, M.Sc. selaku koordinator RPI penelitian ini dan atas saran dan masukan demi kesempurnaan Laporan Hasil Penelitian. Penulis mengucapkan terima kasih kepada Kepala Balai Penelitian Kehutanan Makassar atas terlaksananya penelitian "Kajian Strategi Implementasi Kesatuan Pengelolaan Hutan (KPH) di Kabupaten Tana Toraja, Provinsi Sulawesi Selatan". Demikian halnya kepada Kepala Dinas Kehutanan dan Perkebunan Kabupaten Tana Toraja yang telah memfasilitasi pelaksanaan di lapang. Tidak terlupakan tentunya kepada tim peneliti.

\section{DAFTAR PUSTAKA}

Badan Planologi Kehutanan. 2005. Rekalkulasi Penutupan Lahan Indonesia Tahun 2005. Departemen Kehutanan. Jakarta.

Badan Planologi Kehutanan. 2006. Rancangan Pembangunan KPH Model Tana Toraja. Pusat Pembentukan Wilayah Pengelolaan Kawasan Hutan 
Departemen Kehutanan-Balai Pemantapan Kawasan Hutan Wilayah VII, Makassar-Dinas Kehutanan dan Perkebunan Kabupaten Tana Toraja.

Balai Pemantapan Kawasan Hutan Wilayah VII Makassar. 2005. Master Plan Rehabilitasi Hutan dan Lahan Sulsel. Makassar.

Balai Penelitian Kehutanan Makassar. 2008. Kajian pembangunan kesatuan pengelolaan hutan $(\mathrm{KPH})$ di Sulawesi (Analisis rancangan dan implementasi kesatuan pengelolaan). Laporan Hasil Penelitian BPK Makassar. Tidak diterbitkan.

Fathoni, T.,2007. Menata kelembagaan menuju KPH mandiri. Makalah Seminar di pada seminar Lustrum IX, Fakultas Kehutanan UGM di Yogyakarta, pada tanggal 6-8 November 2008.

Keputusan Menteri Kehutanan No. 230/2003 tentang Pembentukan Kesatuan Pengelolaan Hutan Produksi (KPHP). Jakarta.

Peraturan Pemerintah No.6/2007 tentang Tata Hutan dan Penyusunan Rencana Pengelolaan Hutan, serta Pemanfaatan Hutan.

Peraturan Kepala Badan Planologi No.80/2006 tentang Pedoman Pembangunan Kesatuan Pengelolaan Hutan (KPH) Model. Jakarta.

Pusat Bahasa Depdiknas. 2003. Kamus Besar Bahasa Indonesia. Edisi Ketiga. Balai Pustaka. Jakarta.

Rangkuti, Freddy. 2008. Analisis SWOT Teknik Membedah Kasus Bisnis. PT Gramedia Pustaka Utama. Jakarta.

Singer, Paula M. 2009. The Infopeople Project dalam Leading Change - Winter, supported by the U.S. Institute of Museum and Library Services. California. Http://infopeople.org/training/past/2009/bls_leading_change/ex3_force_ field.pdf Diakses pada tanggal 24 Desember 2009.

Undang-Undang Republik Indonesia No. 41/1999 tentang Kehutanan. Biro Hukum Departemen Kehutanan. Jakarta 
Jurnal Analisis Kebijakan Kefutanan

Vol. \& No. 2, Agustus 2011: $167-188$

Lampiran 1. Matriks internal - eksternal dari Wheelen

Appendix 1. Internal-external factors matrix

TOTAL NILAI FAKTOR STRATEGIS INTERNAL

3,0

2,0

1,0

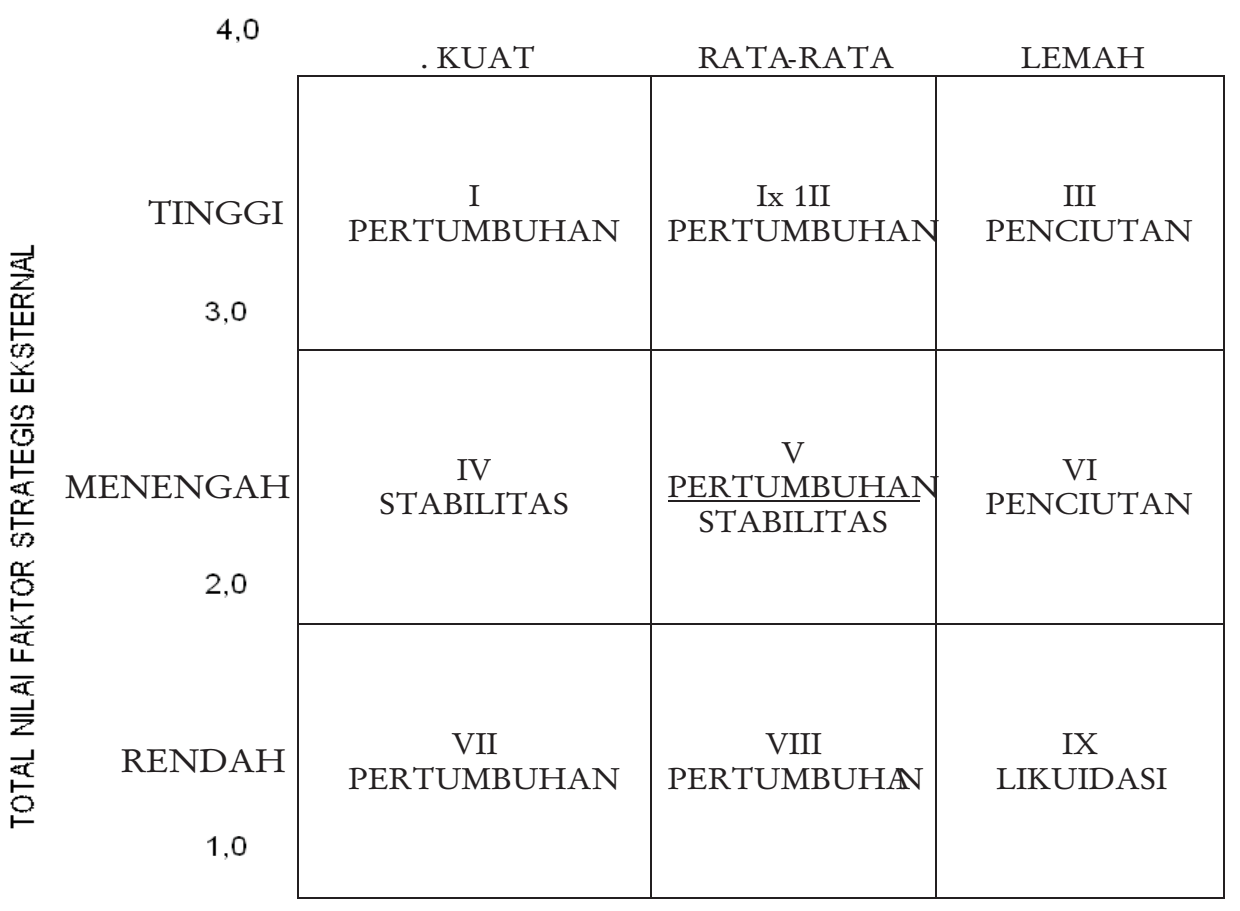

Sumber (Source) : Wheelen (1995) dalam Rangkuti (2008) 